\title{
Social Innovation: A Social Shared Competence
}

\section{Innovación Social: Una competencia social compartida \\ Martha Leticia Silva Flores, Álvaro Rafael Pedroza Zapata}

Centro para la Gestión de la Innovación y la Tecnología ITESO.

Universidad Jesuita de Guadalajara

pamcar@iteso.mx, +52 (33) 12951684, (https://orcid.org/0000-0003-0343-8959)

apedroza@iteso.mx, +52 (33) 36693434, (https://orcid.org/0000-0002-9877-4957)

\begin{abstract}
The article analyzes a conceptual framework to compares experiences of social innovation in Latin America, finding social innovation as a social shared competence, that crosses the borders between social and economic areas. The selected experiences are originated and guided by the satisfaction of a human need and the generation of relationships between individuals and groups of different spaces and scale. The impact of those experiences is recognized under the understanding of social innovation as a shared competence among actors. It is concluded that the different conceptualizations lead to a conceptual framework in which three key elements are proposed for their understanding: first, the orientation to social values; second, the human factor as motor, promoter and source of development; and third, alliances between different actors.
\end{abstract}

\section{Keywords}

Social Innovation; Social Innovation in Latin America; Social Entrepreneurship

\section{Resumen}

En el artículo se analiza un marco conceptual que contrasta experiencias de innovación social que han surgido en América Latina, que sitúa a la innovación social como una competencia social compartida, que rebasa la frontera entre lo social y económico. Para dar cuenta de lo anterior, se seleccionaron experiencias que se originan y orientan por la satisfacción de la necesidad humana y por la generación de relaciones entre individuos y grupos de diferentes espacios y escalas. Se reconoce el impacto de las experiencias entendiendo la innovación social como una competencia que se comparte entre los actores. Se concluye que las diferentes conceptualizaciones llevan a un marco conceptual en donde se proponen tres elementos clave para su entendimiento: primero, la orientación hacia valores sociales; segundo, el factor humano como motor, promotor y fuente de desarrollo; y tercero, las alianzas entre diferentes actores.

\section{Palabras clave}

Innovación social; Innovación social en América Latina; Emprendimiento social

\section{Introduction}

One of extraordinary challenges of Latin America are the social and regional disparities. There are regional disparities within cities, in urban peripheries, disparities in access to education, health, culture, basic services, and sanitation, among others. Potential solutions for these challenges involve a technological component, innovation, and attention to human needs.

In 2014, a team from ESADE's Institute for Social Innovation, led by Heloise Buckland and David Murillo, carried out research and consultancy work under the auspices of the Multilateral Investment Fund (MIF) of the Inter-American Development Bank (IDB), in order to generate a conceptual base and a practical study on the development of social innovation projects in Latin America. This work gave rise to three publications: Social Innovation in Latin America. Conceptual framework and agents, which analyzes the trends of the sector at international level and offers a map of the main actors at the social innovation 
ecosystem in Latin America. Case studies were also developed: Social Innovation in Latin America. Socialab. Promoting creativity to fight against poverty and Social Innovation in Latin America. Share with Colombia. A broker of Social Innovation. The analysis of this type of projects in Latin America allows to recognize the main characteristics enabling the best social innovation practices. Having these works as reference, this article seeks to answer the research question: Which are the main characteristics that lead social innovation projects to be successful in Latin America?

As an axis of study, this article aims to analyze the conceptual framework and contrast it with experiences of social innovation emerged in Latin America, in order to complement the construction of a conceptual framework related to social innovation and review the catalog of actors of social innovation in Latin America synthesizing the main actions reported in the different available media.

The theoretical focus of the article is based on the analysis of the concept of 'social innovation' derived, in the first instance, from uniting two universal terms: the 'innovation' and the 'social.' Literature offers a diverse set of definitions relative to both. The "social" concept is very extensive, but in its broadest sense, there is a generalized consensus in defining it as relative or pertaining to society (Encyclopedia Britannica, 2015). However, for the concept "innovation", each author presents a new definition according to the context and the time in which it develops, perhaps one of the most cited in the literature is that provided by Schumpeter (1969), for whom "Innovation consists not only in new products and processes but also in new forms of organization, new markets and new sources of raw materials." That is to say, innovation is understood as a mechanism of adaptation to the new times and new forms of organization in society.

However, the concept of innovation has been strengthened with specific characteristics that can refer to open, technological, frugal innovation and, even, social practices. For example, Tuomi (2002) places a social element in the conception of innovation that represents different forms of generation and use of knowledge among actors and reference contexts as social practices.

Another characteristic that has been incorporated is the technological practice. Van Wyk (2004) introduces the technological aspect, proposes that innovation creates social value from the use of technological knowledge, because not only can talk about innovation in economic terms or sociological, and dispense with a technological practice.

Even, the constructivist sociology was responsible for questioning the Schumpeterian perspective, with authors such as Pinch \& Bijker (1987) or Latour (2000), who offer a special look at the relationship between technology and the economy. This perspective changed the understanding of innovative dynamics, where the contents of technological knowledge are analyzed as social processes and these processes, as a product of a network of heterogeneous relationships. 
Innovation understood as a social process has evolved to other innovation schemes, such as open innovation and social innovation as an option to apply knowledge to the solution of social problems. These types of innovations create value from the use of technological knowledge in the generation of social positive externalities.

Under this theoretical approach, the research was placed in a qualitative paradigm, with the intention of considering different perspectives of social innovation, points of contrast, tension, and consensus of the experiences studied. To this end, a "Case Study" methodology was proposed since it allows studying a contemporary phenomenon in its real context (Yin 2009), by allowing the emerging and interpretative character of the object of study. Therefore, this methodology helped fulfill the objective of analyzing the conceptual framework and contrast it with experiences of social innovation that have emerged in Latin America.

A methodological design was implemented to compare six case studies. These were chosen for manifesting different aspects of social innovation in development and represent a typical case at each of their regions. The collection and systematization of the data was inspired by the analysis model of Miles \& Huberman (1994), using different sources and techniques that allow a process of continuous deepening in the documentary work and in the analysis of data.

The data analysis was done under the premise that the existing social innovations in different scenarios allows to recognize characteristics that allow the success of the projects. An exploration of different innovation experiences in Latin America was carried out in order to access information on social innovation in itself and its impact. By reviewing the results, the cases to be documented were decided. The information was compared with notes and different documents. In this way, triangulation of information was carried out (Yin, 2009). This methodological design is proposed as an application of case studies to generate new theories based on empirical validation (Eisenhardt, 1989).

\section{Results}

In accordance with the objective of the first article, the conceptual framework that is reported under the title "Social innovation, a concept under construction" was analyzed, and then contrasted with experiences of social innovation that have emerged in Latin America in the section "Social Entrepreneurship and Social Innovation in Latin America." Thus, both sections are part of the results and serve to complement the construction of a conceptual framework related to experiences of social innovation in Latin America and answer the research question. What are the main characteristics that lead social innovation projects to be successful in Latin America? 


\subsection{Social innovation, a concept in construction}

Innovation as a social paradigm has reached importance time ago, and now is used by politicians and intellectuals as well; although nobody is very sure of what it means. Even, "some academics would like to abandon the notion of Social Innovation completely, arguing that it does not add anything we do not know about innovation and it is too vague to be useful" (Pol \& Ville, 2009, cited in Buckland \& Murillo, 2014). But there are several authors who have used the term social innovation, some of them are collected by Pastor Pérez (2013) in the following table:

\begin{tabular}{|l|l|}
\hline \multicolumn{2}{|l|}{ Zapf (1989) } \\
\hline $\begin{array}{l}\text { Mulgan, Tucker, } \\
\text { Ali \& Sanders } \\
(2007)\end{array}$ & $\begin{array}{l}\text { Social innovations are measured by the fact that they help to solve social problems better } \\
\text { because they increase the capacity of societies to adapt. }\end{array}$ \\
\hline $\begin{array}{l}\text { Phills, Dei- } \\
\text { glmeier \& Miller } \\
\text { (2008) }\end{array}$ & $\begin{array}{l}\text { Social innovation refers to new ideas that work to meet social objectives. They are developed } \\
\text { and spread predominantly by organizations whose primary purpose is social. }\end{array}$ \\
\hline $\begin{array}{l}\text { Murray, Cauli- } \\
\text { er-Grice \& Mul- } \\
\text { gan (2010) }\end{array}$ & $\begin{array}{l}\text { Social innovation is a new solution to a social problem that is more effective, efficient, sus- } \\
\text { tainable; or current solutions through which the value created accumulates above all for }\end{array}$ \\
\hline $\begin{array}{l}\text { LEED's Forum as a whole rather than for private individuals. } \\
\text { of Social Inno- } \\
\text { vation }\end{array}$ & $\begin{array}{l}\text { Social innovations simultaneously satisfy social needs and create new social relationships } \\
\text { or collaborations. These are innovations that are good for society while improving their } \\
\text { ability to act. }\end{array}$ \\
\hline $\begin{array}{l}\text { Social Innova- } \\
\text { tion Exchange }\end{array}$ & $\begin{array}{l}\text { Social innovation seeks new responses to social problems through the identification } \\
\text { and provision of new services that improve the quality of life of individuals and societies; } \\
\text { identifying and implementing new integration processes to the labor market. }\end{array}$ \\
\hline NESTA & $\begin{array}{l}\text { Social innovation is the process of design, development, and growth of new ideas that work } \\
\text { to satisfy urgent needs not met. }\end{array}$ \\
\hline $\begin{array}{l}\text { Source: Pastor } \\
\text { (2013). }\end{array}$ & $\begin{array}{l}\text { Social innovation is innovation that is explicitly for the social and public good. It is a type of } \\
\text { innovation that can be rejected by traditional forms of market provision. }\end{array}$ \\
\hline
\end{tabular}

Table 1. Definitions of social innovation (SI)

The different definitions, illustrated in table 1, have as a common characteristic that social innovation is inspired by the desire to satisfy unresolved social needs. Only two of the authors extend the concept: Murray et al. (2010) extend it in the sense of creating new social relationships and collaborations, improving society's capacity to act, and LEED's Forum of Social Innovation does this by adding new competencies to the labor market and new forms of participation, as elements that contribute to improving the people's quality of life. 
Other authors who also have the social mission as their main characteristic are: Arciénaga (2009), who recognizes that the concept of social innovation was cultivated in countries of Anglo-Saxon tradition with the commitment to create new activity models to develop products and services that satisfy the basic needs of collectives unattended by conventional social and economic institutions; Arias and Aristizábal (2011) place the social mission in the foreground, but also refer to the systemic approach and the sustained participation of people, communities, organizations and institutions in a process of social innovation; Innerarity (2009) points out that the value of social innovation goes beyond traditional innovation, where the priority is not only to introduce a new product to the market or a new process to the industry but with these new products or processes to help social cohesion, the creation of employment and wealth, economic independence, pro-activity, and solidarity.

There are other more ambitious definitions, for example ESADE's Institute for Social Innovation specifies that social innovation shuns all attempts of encapsulation in a closed and precise theoretical space, acquiring a practical and applied approach (Buckland \& Murillo, 2014). Stanford University defines it as a solution to certain problems in a more effective, efficient, and sustainable way, through the creation of social value, changing the roles and relationships between capital, organizations and philanthropy, in order to place society as a whole, above the individual, in the search for the reconstitution of society through the participation of its members (Center for Social Innovation, 2009). Social innovation is presented a social competence shared among the members of a society and can help the promotion of social capital.

Just as Stanford's definition, that of Moulaert, MacCallum, \& Hillier, (2013) considers that social innovation is in society as a whole as a path that depends on the context, which refers to changes in the agenda and agency of the institutions that systemically seek a better inclusion of excluded groups and individuals in various fields of society at different scales. All this variety of definitions allows us to understand that there are multiple fronts in which social innovation develops, but that all of them help society from different points of view (Table 2).

\begin{tabular}{|l|l|l|l|}
\hline Market & $\begin{array}{l}\text { Community } \\
\text { participation }\end{array}$ & $\begin{array}{l}\text { Political-social } \\
\text { participation }\end{array}$ & Social development \\
\hline Zapf, 1989 & & & Rodríguez \& Alvarado, 2008 \\
Mulgan et al., 2007 & Arciniega, 2009 & Murray et al., 2010 \\
Phillips, 2008 & Innerarity, 2009 & Moulaert et al., 2013 & Arias \& Aristizábal, 2011 \\
Social Inn Exchange & LEED's Forum & Peña López, 2014 & Lévesue, 2013 \\
NESTA & & OCDE, 2013 \\
$\begin{array}{l}\text { Stanford-Center Social In- } \\
\text { novation }\end{array}$ & & & $\begin{array}{l}\text { Stanford-Center Social Innovation } \\
\text { IIS - ESADE }\end{array}$ \\
\hline
\end{tabular}


Table 2 shows points of agreement between the approaches of the various conceptualizations and trends towards the different dimensions: labor, material, community, health, and education. It is distinguished that authors who have conceptualized social innovation more recently have a tendency to the community dimension where political and social participation is visible.

\subsection{Social entrepreneurship and social innovation in Latin America}

In this section, social entrepreneurship experiences are characterized, based on the theoretical framework referred to in the previous section, which made it possible to account for what happened in Latin America and complement what was documented by ESADE, the MIF, and the IDB. In addition, to answer the question that gives origin and direction to this article.

The countries that currently have important social entrepreneurship and initiatives in the framework of social innovation are Argentina, Brazil, Chile, Colombia, Costa Rica, El Salvador, Guatemala, Honduras, Mexico, Panama, Paraguay, Peru, Dominican Republic and Uruguay (Naser \& Ramírez, 2014).

ESADE's Institute for Social Innovation, in collaboration with the MIF and the IDB, documents social undertakings in the experience called "social innovation antennas", understanding as "antennas of social innovation organizations that dedicate a part of their financial resources, in addition to knowledge technical, advice and networking, to promote the activity of social innovation in Latin America" (Buckland \& Murillo, 2014). In this sense, we observed a diversity of entities that could be defined as antennas for social innovation, ranging from the most consolidated organizations, such as Ashoka, which promote social entrepreneurship and social innovation by supporting civil society networks and social entrepreneurs, even the new actors, such as System B, which promotes a certification system in the region for "double impact" (social and economic) companies.

Thus, in this article the Buckland \& Murillo (2014) proposal was used to study different experiences of social innovation and characterize them based on their social impact, type of innovation, economic sustainability, intersectoral collaboration, scalability and replicability, to recognize which characteristics lead to successful social innovation projects.

The first representative social innovation project in the region analyzed is: "Chile without paperwork". 


\begin{tabular}{|c|c|}
\hline Summary & $\begin{array}{l}\text { The campaign to digitize public procedures "Chile without paperwork" is part of } \\
\text { the initiative Chile Atiende, the multiservice network of the Chilean State, which } \\
\text { was achieved with the commitment of public institutions and the participation } \\
\text { of citizens to jointly develop services that suit your needs and living conditions. }\end{array}$ \\
\hline Location & Santiago de Chile and operates throughout the country. \\
\hline Foundation year & 2012 \\
\hline Social impact & $\begin{array}{l}\text { It seeks to advance through the technology currently available to de-bureaucratie } \\
\text { the State, bringing the procedures and benefits of public institutions closer to } \\
\text { citizens, by simplifying the requirements of the background. }\end{array}$ \\
\hline Type of innovation & $\begin{array}{l}\text { It is focused on simplifying and digitizing those procedures most used by citizens } \\
\text { and which are still carried out in person so that they are now done through more } \\
\text { than } 150 \text { points of service, a call center, and a web portal. }\end{array}$ \\
\hline $\begin{array}{l}\text { Economic } \\
\text { sustainability }\end{array}$ & Cashflow comes from the Chilean federal government. \\
\hline $\begin{array}{l}\text { Cross-sector } \\
\text { collaboration }\end{array}$ & $\begin{array}{l}\text { It achieves the intersectoral articulation of the State, using interoperability } \\
\text { resources from different government institutions, to avoid requesting the } \\
\text { presentation of documents that have previously been issued by another public } \\
\text { administration institution. }\end{array}$ \\
\hline $\begin{array}{l}\text { Scalability and } \\
\text { replicability }\end{array}$ & $\begin{array}{l}\text { The methodology of open data, the characterization of the presentation of the } \\
\text { procedures and the mapping of the institutions are easily replicable and scalable } \\
\text { elements. }\end{array}$ \\
\hline
\end{tabular}

Table 3. Chile without paperwork

The next two cases come from the CEPAL-W. K. Kellogg Foundation contest, which brings together 72 finalist initiatives among 4,800 applications that have been presented in the five cycles of the contest. Each experience, besides being an excellent social practice, are innovative projects. The process to be evaluated considers it benefits a significant group of people, if it arise from the interested parties, it has passed the experimentation phase and if it can be reproduced on a large scale, for which it includes a field visit and a strict system of evaluation. The last documented cycle was 2008-2009, and the first two places were experienced by Brazil and Mexico, respectively: 


\begin{tabular}{|c|c|}
\hline Summary & $\begin{array}{l}\text { It is a methodology developed by the social observatory of Maringá, which works as a } \\
\text { tool of social control to prevent the diversion of funds and the misappropriation of public } \\
\text { resources, capable of ensuring the transparency of bidding processes. }\end{array}$ \\
\hline Location & Maringá, state of Parná, Brazil, with operation in 50 cities of the country. \\
\hline Foundation year & 2006 \\
\hline Social impact & $\begin{array}{l}\text { Drastic reduction in the misappropriation of public funds through bidding processes. In } \\
\text { the first nine months of intervention, the saving was five million dollars. Empowerment } \\
\text { of citizenship and awareness of the need to pay taxes. In 2008, he received the FINEP } \\
\text { Prize, awarded by the Ministry of Science and Technology as one of the five best cases } \\
\text { of Social Technology in Brazil. This model is already used in more than } 50 \text { cities in Brazil. }\end{array}$ \\
\hline Type of innovation & $\begin{array}{l}\text { It is a methodology of social control to achieve transparency and accountability, in order } \\
\text { to prevent corruption, it is followed, in real time, bidding processes from the preparation } \\
\text { of the specifications to the conclusion of the process and the delivery to the satisfaction } \\
\text { of the good or service acquired. As of 2008, this work is extended to the City Council, } \\
\text { extending the action beyond the bids, to the supervision of all other expenses incurred. } \\
\text { This makes possible a reduction of expenses in things such as travel, telephone, fuel, } \\
\text { and personnel. A reduction in the number of civil servants appointed for political reasons } \\
\text { is achieved, by putting pressure on public tenders for the hiring of personnel both in the } \\
\text { Council and in the Prefeitura. }\end{array}$ \\
\hline $\begin{array}{l}\text { Economic } \\
\text { sustainability }\end{array}$ & The income comes from taxes. \\
\hline $\begin{array}{l}\text { Cross-sector } \\
\text { collaboration }\end{array}$ & $\begin{array}{l}\text { It achieves the collaboration of citizens with city leaders without political party involvement, } \\
\text { representing the Federal Revenue, the Commercial Association, the State University, the } \\
\text { University Center of Maringa, the Brazilian Bar Association, the Rotary Club, the Club of } \\
\text { Lions, the Municipal Secretary and State of Education, among others. They decided to } \\
\text { found the Sociedade Eticamente Responsável (SER), with the objective of stimulating the } \\
\text { exercise of citizenship. }\end{array}$ \\
\hline $\begin{array}{l}\text { Scalability and } \\
\text { replicability }\end{array}$ & $\begin{array}{l}\text { The methodology, whose central ideas are the social recognition of taxes, as the only } \\
\text { sustainable source of resources to realize social justice and the correct and transparent } \\
\text { use of public expenditures, allows scalability and replicability. }\end{array}$ \\
\hline
\end{tabular}




\begin{tabular}{|l|l|}
\hline Summary & $\begin{array}{l}\text { Mexican nostalgic food is a binational investment project of remittances, from the } \\
\text { Foundation for Productivity in the Field, AC (Fuproca), which improves the income and } \\
\text { living conditions of 170 producer families, headed by women who stayed in Oaxaca while } \\
\text { their husbands migrated to the United States. This project seeks to attract the investment } \\
\text { of migrants to local productive developments. }\end{array}$ \\
\hline Location & Ayoquezco de Aldama, Oaxaca, Mexico. \\
\hline Foundation year & 2009 \\
\hline Social impact & $\begin{array}{l}\text { Income of female farmers increased by 50\%, and 300 jobs were created. The new } \\
\text { processing factory has stable staff, where the person of the members works. There are } \\
\text { good expectations of growth. The commercialization company has generated direct } \\
\text { income for its members, being able to face the loss of employment due to the financial } \\
\text { crisis. }\end{array}$ \\
\hline $\begin{array}{l}\text { Type of innovation } \\
\text { Economic } \\
\text { sustainability }\end{array}$ & $\begin{array}{l}\text { It is a model of industrialization of backyard production that modernizes the ancestral } \\
\text { practice of growing cactus, generating income higher than subsistence agriculture, } \\
\text { creates added value and jobs, avoids intermediaries and makes possible the export. }\end{array}$ \\
\hline $\begin{array}{l}\text { Cross-sector } \\
\text { collaboration }\end{array}$ & $\begin{array}{l}\text { Revenues come from exports and local sales of packed cactus. } \\
\text { replicability } \\
\text { state government provided inputs to add value to the production of cactus, the National } \\
\text { Polytechnic Institute (IPN) advised the industrialization processes, Fuproca promoted } \\
\text { made the steps before the Ministry of Agriculture of the federal government to build } \\
\text { a processing plant, finally joined another company of migrants in California, Chapulín } \\
\text { Distributors Inc., for export. }\end{array}$ \\
\hline $\begin{array}{l}\text { Ihe backyard production industrialization model is applicable not only to "nostalgic" } \\
\text { products but also to any agricultural production. And the export model allows scalability } \\
\text { of the project. }\end{array}$ \\
\hline
\end{tabular}

Table 5. Mexican nostalgic food

A social enterprise similar to the Maringá Social Observatory is Transparencia Venezuela, software for participatory budgeting; initiative awarded by Ashoka in its category of projects that contribute to change the countries' policy. 


\begin{tabular}{|l|l|}
\hline Summary & $\begin{array}{l}\text { Transparency Venezuela and the British embassy in that country have devised a tool for citizens to } \\
\text { directly intervene in the construction of the budget and hirings of their mayorships. }\end{array}$ \\
\hline Location & Venezuela. El Hatillo municipality, southeast of the Venezuelan capital, Caracas. \\
\hline Foundation year & 2004 \\
\hline Social impact & $\begin{array}{l}\text { With the Participatory Budget and Contracting System registration and access is offered to both } \\
\text { citizens and municipalities and is expressed through a survey of the main needs that afflict the } \\
\text { municipality. The system offers a site to follow up the projects from the start-up phase to the } \\
\text { supplier awards, where they can also download all the documents linked to the tender processes. }\end{array}$ \\
\hline Type of innovation & $\begin{array}{l}\text { It is focused on promoting conditions, procedures and factors to prevent and reduce corruption. } \\
\text { This global anti-corruption network allows us to exchange methodologies, tools, and practices to } \\
\text { boost Venezuela towards international standards. }\end{array}$ \\
\hline $\begin{array}{l}\text { Economic } \\
\text { sustainability }\end{array}$ & $\begin{array}{l}\text { The revenues come from different organizations: Transparency International, Center on Budget and } \\
\text { Policy Priorities, FUNDAR, Analysis and Research Center AC, British Embassy, Embassy of Canada, } \\
\text { Embassy of Norway, European Union and Latin American Network of Legislative Transparency. }\end{array}$ \\
\hline $\begin{array}{l}\text { Cross-sector } \\
\text { collaboration }\end{array}$ & $\begin{array}{l}\text { The collaboration of civil associations non-profit, non-partisan, plural and without political affiliation, } \\
\text { with the government of El Hatillo municipality, Venezuela. }\end{array}$ \\
\hline replicability & $\begin{array}{l}\text { The methodology of open data, the characterization of software adaptable to the realities of each } \\
\text { municipality, are easily replicable and scalable elements. }\end{array}$ \\
\hline
\end{tabular}

Table 6. Transparency Venezuela, software for participatory budgeting

Another, winning initiative of the Ashoka contest is the Indigenous Business and Local Communities Confederation of Mexico (CIELO), a project that has an impact on marginalized groups.

\begin{tabular}{|c|c|}
\hline Summary & $\begin{array}{l}\text { Cecilio Solís, of Nahuatl origin, created the business organization that contributes to the } \\
\text { improvement of the economic, productive and commercialization conditions of the social micro- } \\
\text { enterprises of indigenous and local producers, through the attention and effective response to the } \\
\text { main needs of productive efficiency; currently has } 83 \text { companies dedicated to different economic } \\
\text { sectors, where members of } 33 \text { indigenous peoples participate. }\end{array}$ \\
\hline Location & 22 states of Mexico. \\
\hline Foundation year & 2014 \\
\hline Social impact & $\begin{array}{l}\text { The cultural revaluation and the use of biodiversity, focused on a generation of jobs and the growth } \\
\text { of local organizations, in addition to obtaining greater resources and whose strength lies in its } \\
\text { ethnic-business diversity that keeps in itself culture, art, biodiversity, tradition, and innovation. }\end{array}$ \\
\hline Type of innovation & Capacity building model for ecotourism management in indigenous actors. \\
\hline $\begin{array}{l}\text { Economic } \\
\text { sustainability }\end{array}$ & Through the sale of tourist services, mainly accommodation and recreational activities. \\
\hline $\begin{array}{l}\text { Cross-sector } \\
\text { collaboration }\end{array}$ & $\begin{array}{l}\text { There is the participation of the State government. And they connect with the educational and } \\
\text { tourism sectors. }\end{array}$ \\
\hline $\begin{array}{l}\text { Scalability and } \\
\text { replicability }\end{array}$ & The methodology of the training model is a replicable and scalable element. \\
\hline
\end{tabular}


It can also account for experiences of social innovation that have not emerged from competitions, for example the case study developed by the ESADE Business School in 2014, under the impulse and supervision of the MIF (IDB). Its objective is to understand the central role of a key broker, aimed at eradicating poverty, in the ecosystem of social innovation in Colombia.

\begin{tabular}{|l|l|}
\hline Summary & $\begin{array}{l}\text { Compartamos con Colombia is a non-profit organization that articulates } \\
\text { professional advice to the social sector, offers sustainability consulting for the } \\
\text { private sector and promotes various social innovation initiatives. }\end{array}$ \\
\hline Location & Bogotá, Colombia, and operates in various regions of the country. \\
\hline Foundation year & 2001 \\
\hline Social impact & $\begin{array}{l}\text { He has advised 250 foundations in institutional strengthening and 24 companies } \\
\text { in social responsibility, has participated in public policy to create a multisectoral } \\
\text { platform for social innovation. }\end{array}$ \\
\hline $\begin{array}{l}\text { Type of } \\
\text { innovation }\end{array}$ & $\begin{array}{l}\text { It has a "multifirm" organizational model, has created the first impact investment } \\
\text { fund in Colombia. In addition, it has been a pioneer in the implementation of open } \\
\text { innovation competitions and participatory community innovation methodologies. }\end{array}$ \\
\hline $\begin{array}{l}\text { Economic } \\
\text { sustainability }\end{array}$ & $\begin{array}{l}\text { The income comes from consulting services, contributions from partner } \\
\text { companies and resources associated with social innovation projects. They hold } \\
\text { a team of 31 professionals with an annual invoice of 2.6 million dollars. }\end{array}$ \\
\hline $\begin{array}{l}\text { Cross-sector } \\
\text { collaboration } \\
\text { replicability }\end{array}$ & $\begin{array}{l}\text { It achieves the articulation between the professional services sector and non- } \\
\text { profit entities in Colombia. It also acts as a broker of social innovation between } \\
\text { the public and private sectors, civil society, and social entrepreneurs. }\end{array}$ \\
\hline $\begin{array}{l}\text { The methodologies of open competitions, the characterizations and the } \\
\text { community mappings and the social investment funds are the most easily } \\
\text { refined. }\end{array}$ \\
\hline
\end{tabular}

Table 8. Compartamos con Colombia

The characterization of social impact, type of innovation, economic sustainability, intersectoral collaboration, scalability and replicability of all the experiences of social innovation documented in this article, make visible that social innovation in Latin America emerges from conflicts in spaces of microscale. Social innovation arises from the attention of local problems that open the way to the approach of solutions with the potential to scale and replicate. These approaches of solution, according to the characterized experiences, have a social vision and require promotion strategies of an intersectoral collaboration to generate alliances between the different actors. This finding makes it possible to point to social innovation as a social shared competence.

Since then, it is understood as social shared competence to the set of skills, attitudes, aptitudes, and knowledge that have a specific group of people to enable the development of an action that has as axis to generate social value (Silva-Flores, 2017). 


\section{Discussion}

This article discusses the main contributions to the concept of social innovation and its contrast with the experiences of social enterprises analyzed. Therefore, the discussion is inspired by the authors reviewed and the experiences analyzed. Thus, three key elements that characterize successful social innovation projects and that answer the research question that gave rise to this article are presented.

First, it has a predominance of a social vision, that is, social innovators aim to develop products and services that are aimed at well-being, quality of life, social inclusion, solidarity, citizen participation, environmental quality, health care, the efficiency of public services or the educational level of a society, including the attention to basic human needs (OECD, 2005; Arciniega, 2009).

Second, it focuses on the human factor as a motor, promoter, and source of innovation development. Social innovation is a social construction with a high potential to achieve empowerment a concrete transforming action, generally a collective mode, that offers a response to a problem determined from a linked action of different actors, being the product of social interactions that promote the transformation, development, and articulation of societal capacities that stimulate innovation (Arias \& Aristizábal, 2011; Rodríguez \& Alvarado, 2008).

Third, it is situated in the conflict that is seen as opportunities in microscale spaces that can be carried on a macro scale, which generates important relationships between individual and group initiatives in small communities and allows the construction and facilitation of institutions that can socially enable creative strategies in micro / macro scales (Lévesque, 2013; Moulaert et al., 2013).

From these three elements, social innovation is discovered as a social shared competence, because it is that which emerges from opportunities in microscale spaces, as can be seen in cases of Mexican nostalgic foods or in the Indigenous Business Confederation and Local Communities of Mexico. Cases in which the participation of specific groups of a community is evident, but thanks to the characteristic of scalability and replicability, they have the potential to generate strategies for a macroscale with a predominance of a social vision. That is, this opportunity at the micro level has to be shared with a wider sector of society so that the solution that is given to a specific social group can work for large layers of society.

Also, social innovation is evidenced as a social shared competence in the experiences of Transparencia Venezuela, Maringá Social Observatory and Chile without paperwork. These projects are focused on simplifying and improving procedures, reporting on government decisions and promoting accountability, through intersectoral and inter-institutional collaboration. Being projects promoted by the demand of society, to have access to information on government decisions and promote 
accountability, you can see citizen participation as the origin of social innovation of these projects that promote conditions, procedures, and factors that encourage the empowerment of citizens to prevent and reduce corruption.

In this sense, it can be said that the characterizations of Latin American social innovation experiences show social innovation as a social shared competence both in its end and in its process, not only because it focuses on the social capital factor, such as the main promoter of innovation; but also, because it arises in co-participation of diverse agents that interact in a region. Therefore, it is necessary that in future research these characteristics be incentivized so that social innovation projects have greater chances of success.

\section{Conclusions}

In this document the reader has been provided with contextual elements on social innovation, diverse conceptions, key aspects and a set of experiences of social enterprises that have arisen in Latin America, and which have helped to recognize social innovation as a social shared competition; Therefore, to conclude, the main findings that answered the question that gave rise and direction to the article are reiterated: What are the main characteristics that lead social innovation projects to be successful in Latin America?

With the results shown, it was recognized that social innovation projects are mainly characterized by being driven by collaboration between different actors, which makes it possible to extract the greatest possible value from the innovative potential of the social capital of a city or region. Another characteristic was its origin and orientation that was placed in the satisfaction of human need and in the promotion of the generation of relationships between individuals and groups of different spaces and scales.

These main characteristics of the experiences studied, allowed to recognize in social innovation projects the impact on the empowerment of citizenship with initiatives that are born from the community and from a specific group of people that can be a bridge for a more far-reaching change in the extent that other actors get involved. Therefore, social innovation was considered in the light of the results as a social shared competence that depends on the context, which refers to the changes in the agenda and the agency of the institutions, and which leads to a better inclusion of groups and individuals excluded in various fields of society at different scales.

According to the stated objective, the analysis of the conceptual framework reported and the contrast of this with the experiences of social innovation, three key elements were proposed from the different conceptualizations of social innovation, so that the promotion of social innovation projects has greater 
chances of success. First, the orientation to social values; second, the human factor as motor, promoter and source of development; and third, alliances between different actors that can take advantage of opportunities in microscale space that can be carried out on a macro scale.

These aspects are visible in the different experiences reported in this article that give the perspective that "the ability to innovate is not an individual skill" (Rodríguez \& Alvarado, 2008), nor is it the sum of a series of individual aptitudes. Because, it is a social competence shared by the social actors that are part of relevant practices to bring about social changes; because it goes beyond the border between the social and the economic. Unlike other types of innovation social value is above economic value, this means that the use of knowledge in an innovative way not only generates economic gains but can also solve social problems. In this sense, social innovation can be present in the sector of market economy, in education, in culture, and in social participation fields, because it extends the concept of innovation to society.

\section{References}

Arciénaga, A. (2009). Social Innovation and Social Technologies: Similarities and Differences, Political Approach, pp. 22-34.

Arias, J. \& Aristizábal, C. A. (2011). Transfer of knowledge oriented to social innovation in the relation science-technology and society. Thought and management, 31, 137-166.

Buckland, H., \& Murillo, D. (2014). Social Innovation in Latin America. Conceptual framework and agents, Inter-American Development Bank: Institute of Social Innovation of Esade and Multilateral Investment Fund.

Buckland, H., Carreras, I., \& Murillo, D. (2014). Compartamos con Colombia. A broker of social innovation. Institute of Social Innovation of Esade and Multilateral Investment Fund BID.

Center for Social Innovation. (2009). Social Innovation. Retrieved on June 1, 2015, from Stanford University: http://csi.gsb.stanford.edu/social-innovation

ECLAC, (2011). Mexican nostalgic foods, Retrieved on July 16, 2015, from Experiences in Social Innovation in Latin America and the Caribbean: http://www.cepal.org/dds/innovacionsocial/e/ proyectos/mx/remesas/

ECLAC, (2011). Maringá Social Observatory, Retrieved on July 16, 2015, from Experiences in Social Innovation in Latin America and the Caribbean: http://www.cepal.org/dds/innovacionsocial/e/ proyectos/br/maringa/ 
Eisenhardt, K. M. (1989). Building theories from case study research. Academy of Management Review, 14, 532-550. doi:https://doi.org/10.5465/amr.1989.4308385

Freeman, C. (1995). National System of Innovation in Historical Perspective. Cambridge Journal of Economics, 19(1), 5-24.

Innerarity, D. (2009). "The society of innovation". In How is an innovative society? Madrid: Innobosque.

King of Marulanda, N., \& Tancredi, F. B. (2010). From Social Innovation to Public Policy. Santiago de Chile: Economic Commission for Latin America and the Caribbean (ECLAC).

Latour, B. (2000). Ciência em ação - how to follow scientists and engenheiros sociedade afora. (Translated by Ivone Benedetti). São Paulo: Unesp.

Lévesque, B. (2013). Social innovation in governance and public management system: towards a new paradigm? In F. Moulaert, D. MacCallum, A. Mehmood, and A. Hamdouch, The International Handbook on Social Innovation. London: MPG Printgroup. doi:https://doi.org/10.4337/9781849809993.00012

Miles, M., \& Huberman, M. (1994). Qualitative Data Analysis. Los Angeles: SAGE Publications.

Modern Encyclopedia, (2015). Social realism, Retrieved on June 10, 2015, from Encyclopædia Britannica: http://www.moderna.eb.com.ezproxy.iteso.mx/ee/article-9426388

Moulaert, F., MacCallum, D., \& Hillier, J. (2013). Social innovation: intuition, precept, concept, theory, and practice. In F. Moulaert, D. MacCallum, A. Mehmood, \& A. Hamdouch, The International Handbook on Social Innovation (pp. 13-24). Massachusetts: Edward Elgar. doi:https://doi. org/10.4337/9781849809993.00011

Murray, R., Caulier-Grice, J., \& Mulgan, G. (2010). The Open Book of Social Innovation: Ways to Design, Develop and Grow Social Innovation. London, UK: NESTA.

Naser, A., \& Ramírez, A. (2014). Open government plan. A roadmap for the governments of the region. In ECLAC: United Nations, Santiago, Chile.

OECD. (2013). Start-up Latin America: Promoting Innovation in the Region. Studies of the Development Center: OECD Publishing.

OECD / European Communities, (2005). Oslo Manual: Guidelines for Collecting and Interpreting Innovation Data. $3^{\text {rd }}$ ed.

Pastor Pérez, M. del P. (2013). Microcredit as a financing instrument for development: Reflections based on innovation. In L. V. Mballa (Ed.), Microfinance of local development in Mexico (pp. 31-52). San 
Luis Potosí: UASLP.

Pinch, T. \& Bijker, W. (1987). The social construction of facts and artifacts: Or how the sociology of science and the sociology of technology might benefit each other. In: Bijker, Wiebe, et al. (eds.), The social construction of technological systems. Mass., Cambridge: MIT Press.

Rodríguez, A. \& Alvarado, H. (2008). Keys to social innovation in Latin America and the Caribbean. Santiago de Chile: Cepal.

Schumpeter, J. (1969). Theory of Economic Development. Mexico: Economic Culture Fund.

Silva-Flores, M. L. (2017). Social innovation in emerging innovation infrastructures in middle-income countries: Guadalajara, Mexico. Mexico [e-book]. ITESO

Solís, C. (2004). Cultural revaluation and the use of biodiversity. Retrieved on July 16, 2015, from https://www.ashoka.org/fellow/cecilio-solis

Tuomi, I. (2002). Networks of Innovation: change and meaning in the age of the Internet. New York: Oxford University Press.

Van Wyk, R. J. (2004). A template for graduate programs in management of technology (MOT). Report to the Education Committee, International Association for Management.

Yin, R. (2009). Case study research: Design and methods. Newbury Park, CA: Sage. 